\title{
Evaluation Of Local Carbon Sources In The Biofloc System For Juvenile Pangasius-Pangasius Culture Using Small-Scale Plastic Pond In Central Java, Indonesia
}

\author{
Purnama Sukardi $^{1 *}$, Norman A. Prayogo ${ }^{2}$, Taufik Budhi Pramono ${ }^{1}$, Agung Sudaryono ${ }^{4}$ and \\ Taufan Harisman ${ }^{3}$ \\ ${ }^{1}$ Department of Aquaculture, ${ }^{2}$ Depatrment of Aquatic Resources Management, ${ }^{3}$ Department of Marine Science, Faculty of \\ Fisheries and Marine Science, Universitas Jenderal Soedirman \\ ${ }^{4}$ Department of Aquaculture, Faculty of Fisheries and Marine Science, University of Diponegoro, Semarang
}

*Corresponding author:Purnama Sukardi, Department of Aquaculture, Faculty of Fisheries and Marine Science, Universitas Jenderal Soedirman, Jl. Soeparno, Purwokerto, 53123, Indonesia; E-mail: purnamas@ unsoed.ac.id; purnamaskd@gmail.com;

mobile +62 8132712 9933; phone +62-281-642360

Received:23 April 2019; Accepted: 30 Juni 2019

\begin{abstract}
Purnama Sukardi, Norman A. Prayogo, Taufik Budhi Pramono, Agung Sudaryono and Taufan Harisman. 2019. Evaluation Of Local Carbon Sources The Biofloc System For Juvenile Pangasius Pangasius Culture Using Small-Scale Plastic Pond In Central Java, Indonesia Aquacultura Indonesiana, 20 (1): 48-56. The aim of the study was to investigate the effect of different types of carbohydrates on growth, survival, feed efficiency and fish production (Pangasius pangasius), in the biofloc system with zero-water exchange. Added carbohydrates were tapioca, molasses, bran and cornstarch which were set at level of $25 \%$ of the theoretical adding quantity. A total of 6000 fish larvae used in this experiments. Complete Randomized Designed was used with four treatments and three replications. Twelve tanks were used in which each tank was a cylinder tank $(1814.92 \mathrm{~L})$ and each tank contained 500 fish. The results showed that the concentrations of ammonia and nitrite differ significantly in the experimental tank with added maize when compared to the other carbohydrate sources. The nitrate levels showed that high concentration was observed in the maize treatments compare to tapioca and molasses treatments, however it was not significantly different than that of rice bran treatments. The floc volume stabilized after about 3 weeks in the BFT tanks. Different carbon sources had resulted in different proximate floc composition tendencies. The highest fish yield obtained in molasses treatments which were highest compare to all carbohydrate treatments, whilst tapioca, rice bran, and maize treatments were not significantly different.
\end{abstract}

Keywords: Pangasius, carbon sources, zero water-exchange

\section{Introduction}

Pangasius pangasius like other tropical freshwater fish (Osphronemus gouramy, Osteochilus hasselti, Clarias batrachus) is very famous and economic viable to the people of Indonesia (Prayogo, et. al., 2016). This species is also commonly found in Asian countries like China (Hogan, et al.2007), Vietnam (Valey, et al. 2012), India (Prabu, et al. 2012; 2013) and Bangladesh (Hannan, et. al. 1988). One of the impacts of global climate change is that water become a limiting factor for aquaculture activities in Java Island Indonesia. Some major issues in this area are increasing of competition in using water with populations and others agriculture and aquaculture activities and maintenance of environmental quality and sustainability of aquaculture system (Yuwono and Sukardi, 2009). Indonesia has a population estimated at 257 million in 2015 and about $58 \%$ of Indonesia's population lives in Java, the most populous island. Zero or minimum water exchange is an example of adaptation activity caused by climate change impacts in aquaculture (The

\section{AQUACULTURA INDONESIANA}

An International Journal of Indonesian Aquaculture Society (www.aquasiana.org)

(C) Copyright by Indonesian Aquaculture Society 2019 
Indonesian Central Bureau of Statistics, 2016; FAO, 2014). Land aquaculture producers increasingly utilize re-circulation aquaculture system which range from high technology particulate filtration, and bio-filtration to less complex technologies such as a simple filtration using natural bio-filtration. These high technologies increase operation and production cost and only expensive product will economically viable. Some aquaculturists reduce water exchange as a strategy for minimizing using water (Badiola, et al.2012; Burr, et al. 2012; Dolan, et al. 2013; Pedersen, et al.2012).

Biofloc technology (BFT) is a promising system for future aquaculture in which water and nutrient can be reuse and recycle continuously (Hargreaves, 2013; Crab, 2012; Schryver, et al. 2008). BFT can provide fish production at high stocking density in a condition that is sustainable and biologically safe (Ray, et al. 2010; Zao, P., et al. 2012; Schveitzer, et al.2013). The system enhances the growth and production of fish and is also maintained water quality (Schveitzer, et al. 2013, De Schryver, et al. 2008). In some studies, the protein content originating from the flock can reduce the need of protein from feed due to the availability of the biofloc protein (Xu, et al. 2012). This sustainable approach base on microorganisms growth in the system and the advantage of the method is minimum or without water exchange $(\mathrm{Xu}$, et al. 2012; Kuhn, et al. 2009; Xu, 2016). The role of organisms inside the system is maintenance of water quality and increasing culture feasibility by reducing feed conversion ratio and decrease of feed costs (Schveitzer, et al. 2013).

A small-scale aquaculture is characterized by small-scale fish farming, small-scale farming house-holds, and the use of appropriate technology. The successful adoption of small-scale aquaculture by poor families is included cage culture in open-access water, in leasing of small ponds for fish raising and raising of fish larvae in the early rice field done (Edwards, 2013). The most important of this study of small-scale backyard biofloc technology without water exchange was to be acquainted with the suitability of small-scale aquaculture that applied to the poor in rural and urban areas, whilst the specific objectives were to quantify the contribution of biofloc technology to fish growth, survival, feed efficiency, and production using different carbon sources locally available.

\section{Materials and methods}

\section{Larval rearing and experimental design}

A total of 6000 fish larvae were used in this experiments. Fish originally from hatchery of a self help group which cooperate with the Department of Aquaculture, Faculty of Fisheries and Marine Science, Jenderal Soedirman University. Complete Randomized Designed (CRD) was used with four treatments and three replications. Twelve tanks used in which each tank was a cylinder tank (1814.92 L) and each tank contained 500 fish (equivalent to a fish density of $3.63 / \mathrm{L}$ water volume). The tank were aerated with air stones. The study was carried out for a period of nine weeks between July and September 2016. During culture period, water in the tanks was not exchanged aside from freshwater addition due to the evaporation. Feeding rates set at $3 \%$ of the total stocked biomass daily in the first several days and then accustomed weekly after weighing a fish sample. Commercial pellets contain crude protein, crude lipid, crude fiber, ash and moisture (32\%, 4\%, 5\%, 11.5 and $12 \%$, respectively). The pellets were applied to fish twice daily at 07:00 $\mathrm{h}$ and 16:00 h. Throughout culture period, four different carbon sources i.e. tapioca, molasses, rice bran, and maize were added in to BFT tanks to promote the development of bioflocs, which maintained suitable water quality and to provide supplemental protein source. Three tanks prepared for every carbon sources and carbon was added to the tanks every day $(06: 00 \mathrm{~h})$ at a level $25 \%$ of the theoretical quantity. The theoretical adding quantity of carbohydrate sources calculated according to Avnimelech (1999). In the previous study, carbohydrate addition set at a level of 50\% was regarded as too much, thus in this study carbohydrate sources were set at level of $25 \%$ of the theoretical quantity. Carbohydrate source was mixed well and spread out to the water tank at 07.00 $\mathrm{h}$ and 16:00 h. Parameters of fish growth performance, i.e., the body weight, survival, and yield, were determined at the 
culture end of the experiment and the efficiency parameter, as well. Surviving fish from each tank counted and final body weight (wet weight) recorded.

\section{Floc collection and water analysis}

Imhoff cone used to determine on site bioflocs volume (Avnimelech and Kochba, 2009). A nylon bag with a $10-\mu \mathrm{m}$ mesh size used to take biofloc samples by filtering water from each tank. Samples dried in an oven at $105{ }^{\circ} \mathrm{C}$ until constant weight, pooled together and then stored at $-20{ }^{\circ} \mathrm{C}$ until proximate composition analysis ( $\mathrm{Xu}$, et al, 2012). Water sample were collected from each tank and analyzed spectrophotometrically for total ammonia nitrogen (TAN), nitrite nitrogen $(\mathrm{NO} 2--\mathrm{N})$ and nitrate nitrogen $(\mathrm{NO} 3--\mathrm{N})$ according to the standard methods for water and waste water analysis (APHA, 1998). A digital oxygen-meter (YSI 55, Yellow Springs, OH, USA) used to measure dissolved oxygen and water temperature. The $\mathrm{pH}$ measured using a digital $\mathrm{pH}$ meter (Hanna
HI98128 pH meter). Agricultural lime $(\mathrm{CaCO} 3)$ added when the $\mathrm{pH}$ drops below 7.

\section{Statistical analysis}

One way analysis of variants (ANOVA) by the SPSS (version 14) statistical package was used to compare growth, survival, yield, and efficiency parameters. When a main effect was significant, the ANOVA followed by Tukey's multiple range tests to identify differences among experimental groups. Significant level was set at $95 \%$ probability levels. Prior to analysis, arcsine-transformation applied to the percentage and ration data. Normality and homogeneity of variances was checked before analysis. Survival rate (SR), feed conversion rate (FCR) and yield were calculated using the following equations: Survival rate $(\%)=100$ $\times$ (final fish count/initial fish count), Feed conversion ratio=total dry weight of feed offered/total fish wet weight gained, Yield= total fish wet weight gained $(\mathrm{kg}) /$ volume of fish- pond (m-3).

\section{Result and discussion}

\section{Water quality parameters}

Table 1. Water quality parameters after nine weeks of growth in BFT system using four different carbon sources for the cultivation of Pangasius pangasius

\begin{tabular}{lllll}
\hline Parameter & Tapioca & Molasses & Rice Bran & Maize \\
\hline Temperature $\left({ }^{\circ} \mathrm{C}\right)$ & $27.7 \pm 0.29^{\mathrm{a}}$ & $27.6 \pm 0.26^{\mathrm{a}}$ & $27.5 \pm 0.30^{\mathrm{a}}$ & $27.6 \pm 0.29^{\mathrm{a}}$ \\
$\mathrm{pH}$ & $7.6 \pm 0.6^{\mathrm{a}}$ & $7.5 \pm 0.12^{\mathrm{a}}$ & $7.5 \pm 0.16^{\mathrm{a}}$ & $7.7 \pm 0.08^{\mathrm{a}}$ \\
Dissolved oxygen $\left(\mathrm{mg} . \mathrm{L}^{-1}\right)$ & $7,2 \pm 0.23^{\mathrm{a}}$ & $7.0 \pm 0.2^{\mathrm{a}}$ & $7.2 \pm 0.22^{\mathrm{a}}$ & $7.4 \pm 0.24^{\mathrm{a}}$ \\
Ammonia $\left(\mathrm{mg} \cdot \mathrm{L}^{-1}\right)$ & $0.53 \pm 0.03^{\mathrm{a}}$ & $0.52 \pm 0.03^{\mathrm{a}}$ & $0.54 \pm 0.03^{\mathrm{a}}$ & $0.67 \pm 0.06^{\mathrm{b}}$ \\
Nitrite $\left(\mathrm{mg} \cdot \mathrm{L}^{-1}\right)$ & $0.51 \pm 0.03^{\mathrm{a}}$ & $0.49 \pm 0.02^{\mathrm{a}}$ & $0.52 \pm 0.02^{\mathrm{a}}$ & $0.69 \pm 0.10^{\mathrm{b}}$ \\
Nitrate $\left(\mathrm{mg} \cdot \mathrm{L}^{-1}\right)$ & $3.52 \pm 0.03 \mathrm{ab}$ & $3.38 \pm 0.14 \mathrm{~b}$ & $3.54 \pm 0.03 \mathrm{ac}$ & $3.68 \pm 0.08 \mathrm{c}$ \\
\hline
\end{tabular}

Values in the same row with different superscripts are significantly different $(\mathrm{P}<0.05)$

The results revealed that addition of different carbohydrate sources in the water column had different effects to the ammonia, nitrite, and nitrate levels during the cultivation period in the BFT system (Table 1). However, temperature, $\mathrm{pH}$, and dissolved oxygen not affected by these treatments. The overall mean of water temperature, $\mathrm{pH}$ and DO concentration were not significantly different observed between the carbohydrate treatments which were also within the normal range of tropical fish culture. Ammonia concentrations from the treatment with different carbohydrate sources addition showed a highly significant different between maize and other carbohydrate sources $(\mathrm{P}<0.05)$, however no significant difference was observed among tapioca, rice bran and molasses treatments, respectively. Nitrite concentrations in the BFT system showed a highly significant different between the maize treatments $(0.67 \pm 0.06)$ and other carbohydrate treatments $(\mathrm{P}<0.05)$. Whilst tapioca, molasses, and rice brand treatments were not significantly different observe. The results of the nitrate levels showed that a highly significant different among treatments $(\mathrm{P}<0.05)$ during the rearing 
period. High concentration, $3.68 \pm 0.08$ was observed in the maize treatments compare to tapioca (3.52 \pm 0.03$)$ and molasses $(3.38 \pm 0.14)$, however it was not significantly different than that of rice bran $(3.54 \pm 0.08)$ treatment.

\section{The bioflocs development}

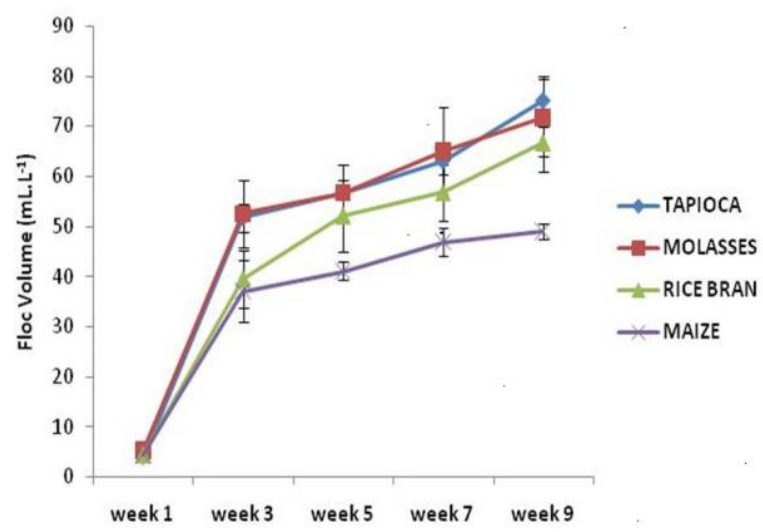

Figure1. Change of floc volume (FV) of four biofloc treatments during the-9 weeks of experimental period. Tapioca, molasses, rice bran, and maize represent four treatments. Values were means $( \pm \mathrm{SD})$ of three replicate tanks per sampling time in each treatment.

The bioflocs development in terms of flocs volume after 15 min sedimentation (FV-15) during experiments showed in Fig.1. FV-15 concentrations increased gradually throughout the experiment period and increasing tendency of them over time are basically consistent. The biofloc volume stabilized after about 3 weeks in the BFT tanks with average $\mathrm{FV}$ concentration of around $43.77 \pm 8.36 \mathrm{~mL}-1$ and the highest of flocs concentrations was in the last week of experiments $(59.48 \pm 9.32 \mathrm{~mL}-1)$. In the week three, the concentration of flocs volume which carbon source derived from tapioca $(56 \pm 2.89)$ and molasses $(62.50 \pm 6.61)$ was significantly higher compare to maize $(37.1 \pm 6.18)$, however the rice brand was not significantly different compare to tapioca, molasses and maize, respectively $(\mathrm{P}<0.05)$. In the week five, the concentration of floc volume derived from maize $(41.07 \pm 1.86)$ was significantly lower than that of molasses $(56.67 \pm 5.77)$, however it was not significantly different compare to tapioca $(53.33 \pm 5.77)$ and rice brand $(41.07 \pm 1.86)(\mathrm{P}<0.05)$. Molasses was not significantly different compare to tapioca and rice brand, as well. In the week seven, the floc volume derived from tapioca $(63.00 \pm 2.65)$ and molasses $(65.00 \pm 8.66)$ was significantly higher compare to maize (46.92 \pm 2.69$)$. The rice brand, $57.73 \pm 5.71$, was not significantly different compare to tapioca, molasses and maize, respectively $(\mathrm{P}<0.05)$. In the week nine, all three carbon treatments (tapioca, molasses and rice brand, 75.00 \pm 5.00 , $71.67 \pm 7.64$ and $66.67 \pm 5.77$, respectively) were significantly higher than that of the maize treatments $(49.10 \pm 1.55)$.

\section{Biofloc nutrition}

Table2. Proximate composition (\%) of flocs from BFT (mean \pm SD), as determined by laboratory analysis $(n=2)$.

\begin{tabular}{lllll}
\hline \multicolumn{1}{c}{ Nutrients } & \multicolumn{1}{c}{ Tapioca } & \multicolumn{1}{c}{ Molasses } & \multicolumn{1}{c}{ Rice Bran } & \multicolumn{1}{c}{ Maize } \\
\hline Organic matter $^{\mathrm{a}}$ & $75.04 \pm 0.70$ & $75.53 \pm 0.47$ & $74.90 \pm 0.47$ & $75.09 \pm 0.63$ \\
Crude protein & $37.18 \pm 0.10$ & $36.72 \pm 0.14$ & $32.73 \pm 0.45$ & $28.69 \pm 0.59$ \\
Crude lipid & $1.58 \pm 0.08$ & $1.81 \pm 0.06$ & $2.30 \pm 0.23$ & $1.87 \pm 0.11$ \\
Crude fiber & $12.14 \pm 0.04$ & $11.75 \pm 0.28$ & $12.17 \pm 0.01$ & $12.21 \pm 0.18$ \\
Moisture & $7.21 \pm 0.89$ & $7.16 \pm 0.08$ & $7.15 \pm 0.36$ & $7.09 \pm 0.23$ \\
Ash & $24.97 \pm 0.70$ & $24.47 \pm 0.47$ & $25.10 \pm 0.47$ & $24.92 \pm 0.63$ \\
NFE & $16.93 \pm 0.03$ & $18.10 \pm 0.06$ & $20.89 \pm 0.08$ & $25.23 \pm 0.11$ \\
${\text { Gross energy }(\mathrm{kcal} / 100 \mathrm{~g})^{\mathrm{c}}}^{\mathrm{b}}$ & $342.26 \pm 2.19$ & $345.08 \pm 2.17$ & $337.36 \pm 3.42$ & $331.79 \pm 4.53$ \\
\hline
\end{tabular}

\section{AQUACULTURA INDONESIANA}

An International Journal of Indonesian Aquaculture Society (www.aquasiana.org) 
a. organic matter=100-Ash (\%)

b. $\mathrm{NFE}=100-(\mathrm{CP}+\mathrm{EE}+\mathrm{CF}+\mathrm{ash}+$ moisture $)$

c. Grossenergy $(\mathrm{GE})=(\mathrm{CP} \times 5.6)+(\mathrm{EE} \times 9.44)+(\mathrm{CF} \times 4.1)+(\mathrm{NFE} \times 4.1) \mathrm{kcal} / 100 \mathrm{~g}(\mathrm{NRC}, 1993)$

The proximate composition of the bioflocs derived from the BFT tanks showed in Table 2. The dried biofloc derived from tapioca, molasses, rice brand and maize additions in the BFT tanks contained $37.18 \pm$ $0.10,36.72 \pm 0.14,32.73 \pm 0.45$ and $28.69 \pm$ 0.59 crude protein, respectively. The crude lipid content of tapioca, molasses, rice brand and maize treatments ranged from $1.58 \pm 0.08$, $1.81 \pm 0.06,2.30 \pm 0.23$ and $1.87 \pm 0.11$, respectively. The mean crude fiber content of tapioca, molasses, rice brand and maize treatments were $12.14 \pm 0.04,11.75 \pm 0.28$, $12.17 \pm 0.01$ and $12.21 \pm 0.18$, respectively. Moisture content of floc from the treatment with tapioca, molasses, rice brand and maize in the BFT tanks was $7.21 \pm 0.89,7.16 \pm 0.08$, $7.15 \pm 0.36$ and $7.09 \pm 0.23$, respectively. The content of ash in floc with carbon source of tapioca, molasses, rice bran and maize was $24.97 \pm 0.70, \quad 24.47 \pm 0.47, \quad 25.10 \pm 0.47$ and $24.92 \pm 0.63$, respectively. The mean nitrogen free extract (NFE) content of tapioca, molasses, rice bran and maize were $16.93 \pm 0.03, \quad 18.10 \pm 0.06, \quad 20.89 \pm 0.08$ and $25.23 \pm 0.11$, respectively. The calculated gross energy $(\mathrm{kJ} / 100 \mathrm{~g})$ of the biofloc of tapioca, molasses, rice bran and maize was $342.26 \pm 2.19,345.08 \pm 2.17,337.36 \pm 3.42$ and $331.79 \pm 4.53$, respectively.

\section{Growth and yield performance}

Table3. Performance of Pangasius pangasius in the BFT with the addition of different carbohydrate sources at the end of experiment

\begin{tabular}{lllll}
\hline Parameter & Tapioca & Molasses & Rice Bran & Maize \\
\hline Weight $(\mathrm{g})$ & $50.57 \pm 3.45^{\mathrm{a}}$ & $49.81 \pm 1.85^{\mathrm{a}}$ & $51.57 \pm 4.49^{\mathrm{a}}$ & $49.19 \pm 1.61^{\mathrm{a}}$ \\
Survival $(\%)$ & $58.3 \pm 1.56^{\mathrm{ac}}$ & $97.5 \pm 0.71^{\mathrm{b}}$ & $50.50 \pm 0.42^{\mathrm{c}}$ & $45.40 \pm 2.40^{\mathrm{d}}$ \\
FCR & $1.04 \pm 0.07^{\mathrm{ac}}$ & $0.63 \pm 0.02^{\mathrm{b}}$ & $1.15 \pm 0.10^{\mathrm{cd}}$ & $1.33 \pm 0.05^{\mathrm{d}}$ \\
Yield $\left(\mathrm{kg} \cdot \mathrm{m}^{-3}\right)$ & $8.05 \pm 1.52^{\mathrm{a}}$ & $12.60 \pm 0.47^{\mathrm{b}}$ & $7.64 \pm 0.50^{\mathrm{a}}$ & $6.49 \pm 0.29^{\mathrm{a}}$
\end{tabular}

Means $( \pm \mathrm{SD})$ of the body weight $(\mathrm{g})$, yield $\left(\mathrm{kg} \mathrm{m}^{-3}\right)$, survival $(\%)$ and FCR. Means within a row followed by different superscript letters were significantly different $(\mathrm{P}<0.05)$.

Growth performance of Pangasius pangasius juvenile during nine weeks of culture presented in Table 3. Body weight calculated through final weight, whilst mean final body weight among treatments not significantly different. Survival showed a highly significant different among treatments $(\mathrm{P}<0.05)$. A better survival, 97.5 \pm 0.71 was observed in molasses treatments which were significantly higher from tapioca $(58.3 \pm 1.56)$, rice brand (50.50 \pm 0.42$)$, and maize ( $45.40 \pm$ $2.40)$, respectively. The tapioca treatments were not significantly different compare to the rice brand treatments; however both treatments were significantly higher than the maize treatments. Feed conversion ratio (FCR) of Pangasius pangasius showed a highly significant different among treatments $(\mathrm{P}<0.05)$. Highly efficient (FCR), $0.63 \pm 0.02$ was observed in molasses treatments which were significantly efficient than that obtained in tapioca, rice brand and maize treatments, $1.04,1.15$ and 1.33 , respectively. The rice brand treatments $(1.15 \pm 0.10)$ were not significantly different compare to tapioca $(1.04 \pm 0.07)$ and maize treatments $(1.33 \pm 0.05)$, however the tapioca treatments were significantly different than that gained in maize treatments. Yield of Pangasius showed a highly significant between carbohydrate treatments $(\mathrm{P}<0.05)$. The highest yield, $12.60 \pm 0.47$ was obtained in molasses treatments which were highest compare to all carbohydrate treatments, whilst tapioca $(8.05 \pm 1.52)$, rice bran $(7.64 \pm 0.50)$, and maize $(6.49 \pm 0.29)$ treatments were not significantly different.

The bioflocs development in terms of flocs volume after $15 \mathrm{~min}$ sedimentation (FV-15) during experiments showed in Fig.1. FV-15 concentrations increased gradually throughout the experiment period and 
increasing tendency of them over time were basically consistent. The floc volume stabilized after about 3 weeks in the BFT tanks with average FV concentration of around $43.77 \pm 8.36 \mathrm{~mL}-1$ and the highest of flocs concentrations was in the last week of experiments $(59.48 \pm 9.32 \mathrm{~mL}-1)$. In the week three, the concentration of biofloc volume which carbon source derived from tapioca $(56 \pm 2.89)$ and molasses $(62.50 \pm 6.61)$ was significantly higher compare to maize (37.1 \pm 6.18$)$, however the rice brand was not significantly different compare to tapioca, molasses and maize, respectively $(\mathrm{P}<0.05)$. In the week five, the concentration of biofloc volume derived from maize $(41.07 \pm 1.86)$ was significantly lower than that molasses (56.67 \pm 5.77$)$, however it was not significantly different compare to tapioca $(53.33 \pm 5.77)$ and rice brand $(41.07 \pm 1.86)(\mathrm{P}<0.05)$. Molasses was not significantly different compare to tapioca and rice brand, as well. In the week seven, the concentration of biofloc volume derived from tapioca $(63.00 \pm 2.65)$ and molasses $(65.00 \pm 8.66)$ was significantly higher compare to maize $(46.92 \pm 2.69)$. The rice brand, $57.73 \pm 5.71$, was not significantly different compare to tapioca, molasses and maize, respectively $(\mathrm{P}<0.05)$. In the week nine, all three carbon treatments (tapioca, molasses and rice brand, 75.00 \pm 5.00 , $71.67 \pm 7.64$ and $66.67 \pm 5.77$, respectively) were significantly higher than that of the maize treatments $(49.10 \pm 1.55)$.

Water quality

In the present study, average water temperature $(27 \mathrm{oC}$, range $26-28 \mathrm{oC}), \mathrm{pH}$ (7.6, range 7-8) and dissolved oxygen (7.2 mg.L-1, range 7.0-7.5) were well within the range for tropical fish culture (Table1). High concentration of toxic $\mathrm{NH} 3$ and $\mathrm{NO} 2$, as aresult of feed waste and excretion of organisms reared at high density, are the main problems in intensive aquaculture system, affecting their survival rates and reduce growth. Ammonia-N and organic carbon increased in response to dietary protein concentration (Anand, et al. 2013; Azim and Little, 2008). Addition of carbohydrate can reduce concentration of ammonia, nitrite and nitrate (Anand, et al.2013, Wang, et al.2015). For growth and reproduction, heterotrophic microorganisms able to consume a large amounts of organic carbon, ammonia and nitrate nitrogen (Wang, et al. 2012). The addition of carbohydrates in the study also showed a similar phenomenon to the decrease in the concentration of ammonia, nitrite and nitrate, but a source of carbohydrates have different effects to the concentration of the chemical compound depends on third type of carbohydrate. The addition of carbohydrates in the study also showed a similar phenomenon to the decrease in the concentration of ammonia, nitrite and nitrate, however a source of carbohydrates have different effects depending on the decrease in the concentratio effective $n$ of these three chemicals. The level of molasses used in this study was effective in preventing significant ammonia accumulation in the culture medium. However, these supplementation levels were not effective in preventing nitrite accumulation. In this study, the supplementation level of tapioca, molasses and rice bran was effectively in preventing significant ammonia and nitrite residues in the culture medium. However these level of maize were not effective in preventing significant ammonia and nitrite residues. Molasses was the most effective to reduce accumulation of nitrate compare to rice bran and maize, but was not significantly effective compare to tapioca.

Floc in the sytem

The fluctuations flock quantity varies significantly between weekly sampling and tends to increase until the end of the study (Fig.1). The Bioflocs are natural food aggregated and suspended particles formed in culture water which contain bacteria, protozoa, nematoda, rotifer, algae, nematodes and detritus material ( $\mathrm{Ju}$ et al., 2008; Ju et al.,2009, Wang, et al.2015). Additionally, many aquatic species obtain nutritional benefit from the microbial biomass and specially reduce the need of dietary protein (Avimelech, 2009). The biofloc provide additional sources of protein, lipid, mineral and vitamins for the fish (Azim, et al. 2008; Wang, et al. 2015).

Proximate composition

Several studies have shown that theaddition of carbon sources in biofloc systems can substitute feeding of aquatic 
organisms and can promote the growth of several different species such as $\mathrm{O}$. mozambicus (Avnimelec, 2007), Macrobrachium rosenbergii (Asaduzzaman, et al. 2008), M. rosenbergii, Oreochromis niloticus, Indian major carp rohu, Labeo rohita (Asaduzzaman , 2010), L. vannamei ( Xu, et al., 2012). Our study showed that different carbon sources had resulted in different proximate composition tendencies (Table2). The tendency of this difference was evidenced by different FCR results, the molasses had significantly lower FCR values $(0.63 \pm 0.02)$, which means more efficient, compared to tapioca, rice bran and maize, $1.04 \pm 0.07,1.15$ \pm 0.10 and $1.33 \pm 0.05$, respectively. Similarly, survival results showed that the addition of molasses produced the highest survival $(97.5 \pm 0.71 \%)$, compared with tapioca, rice bran $(50.50 \pm 0.42)$ and maize, $58.3 \pm 1.56 \%, 50.50 \pm 0.42 \%$ and $45.40 \pm$ $2.40 \%$, respectively.

\section{Conclusion}

Differences in carbohydrate sources added to the biofloc system without water change for P.pangasius cultivation showed that biofloc volume was gradually increasing throughout the experimental period and the tendency to increase biofloc volume over time was basically consistent. There were different effects on the levels of ammonia, nitrite, and nitrate, but the temperature, $\mathrm{pH}$, and dissolved oxygen were not affected by this addition. Carbohydrate sources of cornstarch have higher concentrations of ammonia, nitrite and nitrate when compared to the addition of tapioca, molasses and rice bran. The value of FCR, survival rate and yield indicated that the addition of molasses were more suitable in this biofloc system

\section{Acknowledgments}

This study supported by a grant from the Directorate General of Higher Education and Jenderal Soedirman University, Indonesia.

\section{References}

Anand, P. S Shyne, Kohli, M. P S, Roy, S. Dam, Sundaray, J. K., Kumar, Sujeet, Sinha, Archana, Pailan, G. H., Sukham, Munil kumar. 2013. Effect of dietary supplementation of periphyton on growth performance and digestive enzyme activities in Penaeus monodon. Aquaculture 392-395 ; 59-68.

APHA, 1998. Standard methods for the examination of water and wastewater. In: Clesceri, L.S., Greenberg, A.E., Eaton, A.D. (Eds.), American Public Health Association, American Water Works Association and Water Environment Federation, United Book Press, Washington DC, USA.

Arnold, S.J., Coman, F.E., Jackson, C.J., Groves, S.A., 2009. High-intensity, zero waterexchange production of juvenile tiger shrimp, Penaeus monodon: an evaluation of artificial substrates and stocking density. Aquaculture 293, 42-48.

Asaduzzaman, M., Rahman, M.M., Azim, M.E., Islam, M.A., Wahab, M.A., Verdegem, M.C.J., Verreth, J.A.J., 2010. Effects of $\mathrm{C} / \mathrm{N}$ ratio and substrate addition on natural food communities in freshwater prawn monoculture ponds. Aquaculture 306, 127-136.

Asaduzzaman, M., Wahab, M.A., Verdegem, M.C.J., Huque, S., Salam, M.A., Azim, M.E., 2008. C/N ratio control and substrate addition for periphyton development jointly enhance freshwater prawn Macrobrachium rosenbergii. Aquaculture 280, 117-123.

Avnimelech, Y, 2007. Feeding With Microbial Flocs by Tilapia in Minimal Discharge Biofloc Technology Ponds. Aquaculture, 264 : 140-147.

Avnimelech, Y. and M. Kochba, 2009. Evaluation of nitrogen uptake and excretion by tila- pia in bio floc tanks, using N-15 tracing. Aquaculture 287, 163-168.

Avnimelech, Y., 1999. Carbon nitrogen ratio as a control element in aquaculture systems. Aquaculture 176 (3), 227-235

Azim, M.E. and D.C. Little, 2008. The biofloc technology (BFT) in door tanks: water quality, biofloc composition, and growth and welfare of Nile tilapia (Oreocromis niloticus). Aquaculture: 283, 29-35.

Badiola, M., D. Mendiola and J. Bostock. 2012. Recirculating aquaculture systems (RAS) analysis: Main issues on management and future challenges. Engineering. 51, 26- 35

Burr, G.S., W.R. Wolters, K.K. Schraderb and S.T. Summerfelt. 2012. Impact of depuration of earthy-musty off-flavors on fillet quality of Atlantic salmon, Salmo salar, cultured in a recirculating aquaculture system. Aquacultural Engineering 50, 28-36.

Crab, R., T. Defoirdt, P. Bossier and W. Verstraete. 2012. Biofloc technology in aquaculture: Beneficial effects and future challenges. Aquaculture 356-357, 351-356 
De Schryver, P., R. Crab, T. Defoirdt, N.Boon, W.Verstraete. 2008. The basic of bio-flocs technology:The added value for aquaculture. Aquaculture, 277:125-137. doi:10.1016

Dolan, E., N. Murphy, M. O’Hehir. 2013. Factors influencing optimal micro-screen drum filter selection for recirculating aquaculture systems. Aquacultural Engineering 56 (2013) $42-50$.

Edwards, P. 2013. Review of small-scale aquaculture: definitions, characterization, numbers. Fisheries and Aquaculture Department, Food and Agriculture Organization of the United Nations, Rome (accessed11.7.12)

http://www.fao.org/docrep/013/i 1820e/i1 $820 \mathrm{e} 00 . \mathrm{htm}$

Food Agriculture Organization (FAO), 2014. Climate change adaptation in fisheries and aquaculture. FAO Fisheries and Aquaculture Circular No. 1088. pp.45

Hannan, M.A,, A.K.M.N., Alam, M.A. Mazid, M.N. Humayun, 1988. Preliminary study on the culture of Pangasius pangasius (Hamilton). Bangladesh J. Fish.11:19-22

Hargreaves, J.A. 2013. Biofloc production systems for aquaculture. Southern Regional Aquaculture Center (SRAC) No.4503.

Hogan, Z., I. G. Baird, R. Radtke, M.J. Vander Zanden, 2007. Long distance migration and marine habitation in the tropical Asian catfish, Pangasius krempfi. J.Fish Biology 71,3:818-832

Ju, Z.Y., I.P. Forster, L. Conquest, W.Dominy, 2008. Enhanced growth effects on shrimp (Litopenaeus vannamei) from inclusion of whole shrimp floc or floc fractions to a formulated diet. Aquaculture Nutrition 14, 533-543.

Ju, Z.Y., I.P. Forster, W.G. Dominy, 2009. Effects of supplementing two species of marine algae or their fractions to a formulated diet on growth, survival and composition of shrimp (Litopenaeus vannamei). Aquaculture 292, 237-243.

Kuhn, D.D., G.D. Boardman, A.L. Lawrence, L. Marsh, G.J.F.Jr. George, 2009. Microbial floc meal as a replacement ingredient for fish meal and soybean protein in shrimp feed. Aquaculture 296, 51-57. doi:10.1016/j.aquaculture.2009.07.025

NRC, National Research Council (1993) Nutrient Requirements of Fish. National Academy Press, Washington, DC.

Pedersen, L., K.I. Suhr, J. Dalsgaard, P.B. Pedersen, E. Arvin, 2012. Effects of feed loading on nitrogen balances and fish performance in replicated recirculating aquaculture systems. Aquaculture :338-341, 237-245. doi:10.1016
Pedersen, LF., T. Meinelt, D. L. Straus. 2013. Peracetic acid degradation in freshwater aquaculture systems and possible practical implications. Aquacultural Engineering. 53, 65-71.

Prabu, D L, M. Kavitha, 2012. Special feeding practices for pangasius catfish in Andhra Pradesh. Aqua Culture Asia Pacific, 8: 20-25.

Prayogo, N.A., A. Siregar, P. Sukardi 2016. The Disruptive Effect Mercurychloride $(\mathrm{HgCl})$ on Gene Expression of cGnRH-II, sGnRH, and Estradiol Level in Silver Sharkminnow (Osteochillus hasseltii C.V.) Turkish J. of Fish Aqua.Sci. 16, 1003-1009

Ray A.J., B.L. Lewis, C.L. Browdy and J.W., Leffler. 2010. Suspended solids removal to improve shrimp (Litopenaeus vannamei) production and an evaluation of a plant-based feed in minimal-exchange, super intensive culture systems. Aquaculture: 299, 89-98.

Sahu, B. B., S.K. Sahoo, S.S. Giri, P.C. Das, B. Mishra, A.K. Sahu, A.E. Eknath, P. Jayasankar. 2013. Carcass traits of two marketable size classes of Pangasius pangasius (Hamilton, 1822). J. of Applied Ichtiology, 29,1:226-229).

Schveitzer, R., R. Arantes, M.F. Baloi, P.F.S. Costodio, L.V.Arana, W.Q. Seiffert, E.R. Andreatta. 2013. Use of artificial substrates in the culture of Litopenaeus vannamei (Biofloc System) at different stocking densities: Effects on microbial activity, water quality and production rates. Aquacultural Engineering, 54, 93-103.

The Indonesian Central Bureau of Statistics. 2016. Social and Population. Population Based on Province. Annual reports.

Waley, D., R. Newton, P. Henriksson, Lam, T. P., 2012. Sustainability of the pangasius trade. Aqua Culture Asia Pacific, 8: 32-35.

Wang, G., E.Yu, J.Xie, D.Yu, Z.Li, W.Luo, L.Qiu, Z.Lijiang, Z.Zheng. 2015. Effect of $\mathrm{C} / \mathrm{N}$ ratio on water quality in zero-water exchange tanks and the biofloc supplementation in feed on the growth performance of crucian carp, Carassius auratus. Aquaculture, 443, 98-104.

Wang, G., E.Yu, J. Xie, D. Yu, D. Li, W. Luo, L. Qiu, Z. Zheng, 2015. Effect of C/Nratio on water quality in zero-water exchange tanks and the biofloc supplementation in feed on the growth performance of crucian carp, Carassius auratus. Aquaculture. 443: 98-104.

Wang, M.Z., X. Zheng, H.Z. He, D.S. Shen, H.J. Feng, 2012. Ecological roles and release patterns of acylated homoserine lactones in Pseudomonas sp. HF-1 and their implications 
in bacterial bioaugmentation. Bioresour. Technol. 125, 119- 126

Xia, Y., E.M. Yu, J. Xie, 2012. Analysis of bacterial community structure of bio-floc by PCR-DGGE. J. Fish. China 36 (10), 1563-1571.

Xu, W. J., T.C. Morris, T.M. Samocha. 2016. Effects of $\mathrm{C} / \mathrm{N}$ ratio on biofloc development, water quality, and performance of Litopenaeus vannamei juveniles in a biofloc-based, high-density, zero-exchange, outdoor tank system. Aquaculture, 453: 169-175.

Xu, W.J., L.Q. Pan,and D.H. Zhao, 2012. Preliminary investigation into the contribution of bioflocs on protein nutrition of Litopenaeus vannamei fed with different dietary protein levels in zero-water exchange culture tanks. Aquaculture 350-353, 147-153.

Yuwono, E. and P. Sukardi, 2009. Development of an environment-friendly feeding management for pond-reared fish species in the Segara Anakan Lagoon, Java, Indonesia. Regional Environmental Change, 9 (4):329-333.

DOI 10.1007/s10113-008-0080-6

Zhao, P., J. Huang, X. H. Wang, X.L. Song, C.H. Yang, H.G. Zhang and G.C. Wang. 2012. The application of bioflocs technology in high-intensive, zero exchange farming systems of Marsupenaeus japonicus. Aquaculture: 354-355, 97-106. DOI 10.1016 